\title{
Avaliação qualitativa e quantitativa da microbiota do solo e da fixação biológica do nitrogênio pela soja
}

\author{
Rosinei Aparecida de Souza( ${ }^{(1)}$, Mariangela Hungria(2), Julio Cezar Franchini(2), \\ Ligia Maria de Oliveira Chueire ${ }^{(2)}$, Fernando Gomes Barcellos ${ }^{(2)}$ e Rubens José Campo ${ }^{(2)}$
}

\begin{abstract}
(1) Universidade Estadual de Londrina, Departamento de Química, Caixa Postal 60001, CEP 86051-990 Londrina, PR. E-mail: rosyquimica@yahoo.com.br (2)Embrapa Soja, Caixa Postal 231, CEP 86001-970 Londrina, PR. E-mail: hungria@cnpso.embrapa.br, franchin@cnpso.embrapa.br, ligia@cnpso.embrapa.br, rjcampo@cnpso.embrapa.br
\end{abstract}

\begin{abstract}
Resumo - O objetivo deste trabalho foi definir, para as condições edafoclimáticas do Brasil, níveis aceitáveis de dispersão de alguns parâmetros biológicos, utilizados em estudos de impacto ambiental de novas tecnologias usadas na cultura da soja. Dois ensaios com soja convencional e transgênica foram conduzidos em 11 municípios de seis estados e no Distrito Federal; os parâmetros avaliados foram: carbono e nitrogênio da biomassa microbiana, respiração basal e quociente metabólico microbiano, eletroforese do DNA do solo em géis desnaturantes (DGGE), fixação biológica do nitrogênio, população de rizóbios, número e massa de nódulos secos, ocupação dos nódulos pelas estirpes de Bradyrhizobium, massa de matéria seca da parte aérea, nitrogênio total e nitrogênio como ureídos na parte aérea. A variabilidade temporal de: carbono e nitrogênio, da biomassa microbiana, da respiração basal e do quociente metabólico microbiano foi adequada, e o coeficiente de variação máximo aceitável foi estimado em 35\%. A homogeneidade entre repetições, tratamentos e coletas foi confirmada por DGGE. Em solos pobres em nitrogênio, os parâmetros de massa de nódulos e massa da parte aérea, com coeficiente de variação máximo de 33 e $18 \%$, respectivamente, foram adequados para avaliar a fixação biológica do N, que contribuiu com 72 a $88 \%$ do nitrogênio total da parte aérea.
\end{abstract}

Termos para indexação: Bradyrhizobium, Glycine max, biomassa microbiana, DGGE, monitoramento ambiental, transgênicos.

\section{Quantitative and qualitative evaluations of soil microbes and biological nitrogen fixation in soybean}

\begin{abstract}
The objective oh this work was to define, for edaphoclimatic conditions of Brazil, acceptable levels of dispersion of some biological parameters, used in studies of environmental impact due to the adoption of new technologies with the soybean crop. Two experiments were performed in eleven counties, in six states and in the Federal District, with conventional and transgenic soybean. Evaluated parameters were: carbon and nitrogen of the microbial biomass, microbial respiration, microbial metabolic quotient, electrophoresis of soil DNA in denaturating gradient gel (DGGE), biological nitrogen fixation, number of rhizobial cells, nodule number and nodule dry weight, nodule occupancy by Bradyrhizobium strains, shoot dry weight, total nitrogen in shoot and nitrogen as ureides in shoot. The temporal variability for carbon and nitrogen of microbial biomass, microbial respiration and microbial metabolic quotient was adequate, and the maximum coefficient of variation was estimated at $35 \%$. The homogeneity between replicates, treatments and harvests was confirmed by the DGGE method. In N-poor soils, the parameters of nodules and shoot dry weight, with maximum coefficient of variation 33 and $18 \%$, respectively, were adequate for evaluation of biological nitrogen fixation, which contributed from 72 to $88 \%$ of total nitrogen in shoot.
\end{abstract}

Index terms: Bradyrhizobium, Glycine max, microbial biomass, DGGE, environmental monitoring, transgenics.

\section{Introdução}

Desde a expansão comercial da cultura da soja no Brasil, na década de 1960, grandes esforços foram empreendidos no melhoramento das cultivares e na seleção de estirpes de Bradyrhizobium japonicum e B. elkanii, para tornar viáveis taxas elevadas de fixação biológica do nitrogênio (FBN) (Hungria et al., 2006). Até 94\% do $\mathrm{N}$ requerido pelas cultivares mais produtivas pode ser fornecido pela FBN, o que permite rendimentos superiores a $4.000 \mathrm{~kg} \mathrm{ha}^{-1}$ (Hungria et al., 2006).

A expansão acentuada de áreas cultivadas com soja transgênica no Brasil causa preocupação quanto a garantir a eficiência do processo de FBN. A incorporação 
de genes de tolerância a herbicidas ou inseticidas não deveria afetar a simbiose, contudo, a regulação de outros genes pode ser alterada pela introdução do gene transgênico, e o herbicida específico pode afetar a bactéria (Zablotowicz \& Reddy, 2004). Há preocupação com os possíveis efeitos da transgenia na microbiota do solo, que podem ocorrer pela liberação de novas proteínas na rizosfera, pela persistência de DNA transgênico em material senescente no solo que interage com a microbiota, e pela transferência de genes para microrganismos indígenas (O’Donnell \& Gorres, 1999).

A importância dos microrganismos para a qualidade do solo e da FBN, para a nutrição das leguminosas, tem demandado a análise de diversos parâmetros microbiológicos em ensaios de monitoramento ou de avaliação de impactos ambientais. Contudo, a viabilidade de avaliar esses parâmetros simultaneamente, em larga escala, e com amostras de diferentes agroecossistemas ainda não foi confirmada.

O objetivo deste trabalho foi definir, para as condições edafoclimáticas do Brasil, níveis aceitáveis de dispersão de alguns parâmetros biológicos utilizados em estudos de impacto ambiental de novas tecnologias usadas na cultura da soja.

\section{Material e Métodos}

Foram realizadas avaliações em dois conjuntos de ensaios, em áreas comerciais (Ensaio 1) e em ensaios experimentais (Ensaio 2), conduzidos nas principais regiões produtoras de soja do Brasil (Tabela 1).

Os experimentos com soja convencional (Ensaio 1) foram instalados em delineamento experimental em blocos ao acaso, com três repetições, conduzidos na safra $2002 / 2003$, em propriedades de agricultores em seis municípios tradicionais de produção de soja: São Luiz
Gonzaga, Passo Fundo, Ponta Grossa, Cascavel, Londrina e Dourados. A localização, o clima e tipo de solo de cada local encontram-se na Tabela 1.

As coletas para as análises microbiológicas foram realizadas nos estádios V4 (terceira folha trifoliada estendida e a quarta aberta) e R2 (florescimento pleno). Todas as áreas haviam sido cultivadas com soja com inoculação por vários anos, e apresentavam populações estabelecidas de Bradyrhizobium; entretanto, não se tem informações sobre a inoculação nessas safras, bem como sobre as cultivares utilizadas e o sistema de cultivo adotado. Nenhuma das áreas recebeu fertilizante nitrogenado.

Os experimentos com soja convencional e evento transgênico para tolerância a herbicida foram conduzidos em sete estações experimentais (privadas ou da Embrapa) (Ensaio 2) na safra 2004/2005, em: Ponta Grossa, Londrina, Santo Antônio de Posse, Sete Lagoas, Santo Antônio de Goiás, Brasília e Planaltina; as informações sobre os municípios encontram-se na Tabela 1. As cultivares de soja utilizadas foram a Conquista e a Conquista evento transgênico, que contém uma cópia única de gene para tolerância a um herbicida específico.

Os ensaios foram conduzidos no sistema convencional, e as parcelas foram constituídas de quatro fileiras de $5 \mathrm{~m}$ de comprimento, espaçadas em $0,5 \mathrm{~m}$. O delineamento experimental foi o de blocos ao acaso, com quatro repetições e três tratamentos: 'Conquista' transgênica com herbicida específico; 'Conquista' transgênica com herbicidas convencionais; e 'Conquista' convencional com herbicidas convencionais. A semeadura foi realizada manualmente. As práticas culturais de preparo do solo, fertilização, irrigação, inoculação e controle de pragas foram aplicadas uniformemente em cada ensaio, conforme

Tabela 1. Localização, clima e tipo de solo nos municípios onde os experimentos foram conduzidos ${ }^{(1)}$.

\begin{tabular}{|c|c|c|c|c|}
\hline Município & Clima & Latitude & Longitude & Solo \\
\hline \multicolumn{5}{|c|}{ Ensaio 1: plantio comercial com soja convencional, safra 2002/2003 } \\
\hline São Luiz Gonzaga, RS & Mesotérmico brando, super úmido sem seca & $28^{\circ} 24^{\prime}$ & $54^{\circ} 57^{\prime}$ & LV \\
\hline Passo Fundo, RS & Mesotérmico brando, superúmido sem seca & $28^{\circ} 15^{\prime}$ & $52^{\circ} 24^{\prime}$ & LB \\
\hline Ponta Grossa, PR & Mesotérmico brando, superúmido sem seca & $25^{\circ} 05^{\prime}$ & $50^{\circ} 09^{\prime}$ & LV \\
\hline Cascavel, PR & Subquente, superúmido, subseca & $24^{\circ} 57^{\prime}$ & $53^{\circ} 27^{\prime}$ & NV \\
\hline Londrina, PR & Subquente, superúmido, subseca & $23^{\circ} 18^{\prime}$ & $51^{\circ} 09^{\prime}$ & NV \\
\hline \multicolumn{5}{|c|}{ Ensaio 2: experimento com evento transgênico e soja convencional, safra 2004/2005 } \\
\hline Ponta Grossa, PR & Mesotérmico brando, superúmido sem seca & $25^{\circ} 05^{\prime}$ & $50^{\circ} 09^{\prime}$ & LV \\
\hline Londrina, PR & Subquente, superúmido, subseca & $23^{\circ} 18^{\prime}$ & $51^{\circ} 09^{\prime}$ & NV \\
\hline Santo Antônio de Posse, SP & Subquente, superúmido, subseca & $22^{\circ} 37^{\prime}$ & $46^{\circ} 54^{\prime}$ & AVA \\
\hline Sete Lagoas, MG & Subquente, úmido, 3 meses secos & $19^{\circ} 27^{\prime}$ & $44^{\circ} 14^{\prime}$ & $\mathrm{AV}$ \\
\hline Santo Antônio de Goiás, GO & Subquente, semi-úmido, 4 a 5 meses secos & $16^{\circ} 29^{\prime}$ & $49^{\circ} 18^{\prime}$ & AV \\
\hline Brasília, DF & Quente, semi-úmido, 4 a 5 meses secos & $15^{\circ} 46^{\prime}$ & $47^{\circ} 55^{\prime}$ & LV \\
\hline Planaltina, DF & Quente, semi-úmido, 4 a 5 meses secos & $15^{\circ} 27^{\prime}$ & $47^{\circ} 36^{\prime}$ & LV \\
\hline
\end{tabular}

${ }^{(1)}$ LV: Latossolo Vermelho; LB: Latossolo Bruno; NT: Nitossolo Vermelho; AVA: Argilossolo Vermelho-Amarelo; AV: Argissolo Vermelho. 
recomendações técnicas para a cultura. As coletas foram realizadas nos estádios de pré-plantio (PP), R2 e, em cinco locais, em R8 (maturação plena).

Para as análises quantitativa e qualitativa da microbiota do solo, foram coletadas sete subamostras deformadas de solo $(0-10 \mathrm{~cm})$, na área total da parcela antes do plantio, ou nas entrelinhas após a germinação. As amostras foram transportadas para o laboratório, homogeneizadas e peneiradas (malhas de $4 \mathrm{~mm}$ ), e deram origem a amostras compostas que foram armazenadas em sacos de plástico na geladeira, a $4^{\circ} \mathrm{C}$, pelo máximo de dez dias. Para a análise da diversidade microbiana, subamostras de cada amostra composta foram mantidas a $-80^{\circ} \mathrm{C}$

$\mathrm{A}$ análise do $\mathrm{C}$ e do $\mathrm{N}$ da biomassa microbiana (CBM e NBM) foi realizada com uso do método de fumigaçãoextração (Brookes et al., 1985; Vance et al., 1987). O teor de $\mathrm{C}$ nos extratos foi determinado colorimetricamente, após a oxidação com $\mathrm{Mn}^{3+}$, e o teor de $\mathrm{N}$ nas mesmas frações foi determinado por digestão via úmida, seguida da determinação colorimétrica do $\mathrm{N}$ amoniacal $\left(\mathrm{N}^{-\mathrm{NH}_{4}}\right)$ pelo método de azul de indofenol; os valores de biomassa microbiana obtidos foram expressados em micrograma de $\mathrm{C}$ ou micrograma de $\mathrm{N}$ da biomassa microbiana por grama de solo seco (Franchini et al., 2007). A respiração basal (RB) foi avaliada pela determinação do $\mathrm{C}$ do $\mathrm{CO}_{2}$ $\left(\mathrm{C}-\mathrm{CO}_{2}\right)$, liberado e capturado em uma solução de $\mathrm{NaOH}$ $0,5 \mathrm{~N}$, em amostras não fumigadas, incubadas por dez dias; os valores de respiração obtidos foram expressados em micrograma de $\mathrm{C}-\mathrm{CO}_{2}$ por grama de solo seco por dia. $\mathrm{O} q \mathrm{CO}_{2}$ foi obtido pela divisão da $\mathrm{RB}$ pelo $\mathrm{CBM}$ [( $\mu \mathrm{g}$ de $\mathrm{C}-\mathrm{CO}_{2} \mu \mathrm{g}^{-1} \mathrm{C}$ microbiano $\left.\left.{ }^{-1}\right) \times 10^{4}\right]$.

A extração do DNA total do solo, para o estudo da composição bacteriana, avaliada em gel desnaturante (DGGE), foi realizada em amostras de $0,25 \mathrm{~g}$ de solo, com o Ultraclean Soil DNA Kit, conforme especificações do fabricante. Foram realizadas duas reações de amplificação do DNA total do solo, para a região que codifica o gene 16S rRNA, seguidas pela eletroforese dos produtos de PCR em um aparato de DGGE, e os géis foram corados e fotografados sob radiação UV (Hungria et al., 2003).

A população de rizóbios capazes de nodular a soja foi avaliada pelo método do número mais provável (NMP), com contagem em plântulas de soja da cultivar BRS 133; os resultados foram expressados em número de células por grama de solo seco. No estádio R2, dez plantas de soja foram coletadas ao acaso, em cada parcela, e avaliadas quanto à nodulação e ao crescimento das plantas. As massas da parte aérea e dos nódulos secos foram determinadas após a secagem em uma estufa a $65^{\circ} \mathrm{C}$, com ventilação forçada (aproximadamente 72 horas). Após a pesagem, as folhas e os pecíolos foram moídos, separadamente, em micromoinho (malha de $20 \mathrm{~mm}$ ). Para a determinação do $\mathrm{N}$ total em um analisador automático, a digestão das folhas e pecíolos foi realizada pelo método Kjeldahl. O teor de $\mathrm{N}$ de ureídos nos pecíolos da soja foi determinado segundo Herridge \& Peoples (1990), e a abundância relativa foi estimada em relação ao $\mathrm{N}$ total nos pecíolos e conferida em relação ao teor de $\mathrm{N}$ de nitrato.

Quarenta nódulos de cada parcela foram escolhidos ao acaso, para a análise da ocupação dos nódulos pelas estirpes inoculantes, pelo método de imuno-aglutinação, contra os antígenos somáticos termo-estáveis das estirpes dominantes nos solos brasileiros: SEMIA 5079 (mesmo sorogrupo da SEMIA 566), SEMIA 5080 (mesmo sorogrupo da SEMIA 586), SEMIA 587 e SEMIA 5019.

Os dados foram submetidos ao teste de normalidade das variáveis e de homogeneidade das variâncias (ANOVA) (SAS Institute, 1999). Quando comprovadas a normalidade e a homogeneidade, foram calculadas a média aritmética $(\overline{\mathrm{x}})$ e o desvio-padrão (s). Uma análise comparativa com o SAS confirmou que essas estimativas podem ser feitas também com o Microsoft Excel. No Ensaio 2, após o teste de normalidade e de homogeneidade, quando a significância do valor $\mathrm{P}$ foi confirmada, foi aplicado um teste post-hoc, utilizandose o teste de Duncan (SAS Institute, 1999).

Para a estimativa da precisão experimental, foi utilizado o coeficiente de variação (desvio-padrão/média,

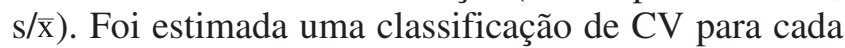
parâmetro, conforme proposto por Garcia (1989), tendo-se considerado todos os CVs disponíveis para cada parâmetro, e tendo-se estimado a média aritmética $(\bar{x})$ e o desvio-padrão da média (s) de cada valor de CV. Com esses valores, procedeu-se à classificação proposta por Garcia (1989) e Ramalho et al. (2005): $\mathrm{CV}<(\overline{\mathrm{x}}-\mathrm{s})$, baixo; $(\overline{\mathrm{x}}-1 \mathrm{~s})<\mathrm{CV}<(\overline{\mathrm{x}}+1 \mathrm{~s})$, médio; $(\overline{\mathrm{x}}+1 \mathrm{~s})<\mathrm{CV}<(\overline{\mathrm{x}}+2 \mathrm{~s})$, alto; $\mathrm{CV}>(\overline{\mathrm{x}}+2 \mathrm{~s})$, muito alto. Os dados também foram analisados considerando-se o índice de variabilidade temporal (IVT), que indica a evolução do CV com o tempo (Wardle, 1998).

Os perfis de DNA fotografados foram analisados pelo programa Bionumerics. A análise de agrupamento foi realizada com o algoritmo UPGMA e o coeficiente de Jaccard, com tolerância estabelecida em 5\% (Hungria et al., 2003).

\section{Resultados e Discussão}

Em razão de o Brasil apresentar diversas condições edafoclimáticas, os parâmetros escolhidos para o tipo de estudo deste trabalho devem mostrar sensibilidade 
aos diversos manejos dos solos e das culturas, e os dados obtidos devem apresentar dispersão ou desvios estatisticamente aceitáveis. Decidiu-se pela utilização do desvio-padrão normalizado (coeficiente de variação, $\mathrm{CV}$ ), como indicativo da precisão dos experimentos.

Com frequiência, em experimentos de campo, são adotados os valores de CV propostos por PimentelGomes (1984): $\mathrm{CV}<10 \%$, baixo; $10 \%<\mathrm{CV}<20 \%$, médio; $20 \%<\mathrm{CV}<30 \%$, alto e $\mathrm{CV}>30 \%$, muito alto; mas um fator limitante nessa classificação é o de que a natureza do parâmetro em análise não é considerada. Baseandose em informações referentes a 146 projetos com Pinus e Eucalyptus, Garcia (1989) sugeriu estabelecer os limites de dispersão dos dados, com base na média aritmética dos CVs e do desvio-padrão da média dos CVs. O uso dessa classificação também foi proposto para outras culturas como milho (Zea mays L.) (Scapim et al., 1995) e citros (Citrus spp.) (Amaral et al., 1997). A natureza dos parâmetros microbiológicos também é distinta e, com freqüência, bastante variável, assim, neste estudo, foram estimadas classes de CV, conforme sugerido por Garcia (1989) e Ramalho et al. (2005). Constatou-se que para os parâmetros de natureza mais variável o valor de dispersão máximo aceitável (classe dos valores médios) pode ser estabelecido em 35\% (Tabela 2).

No Ensaio 1, com avaliações realizadas em propriedades de agricultores, os valores do CBM foram bastante distintos entre as áreas. No estádio V4, os valores variaram de $203 \mu \mathrm{g} \mathrm{C} \mathrm{g}{ }^{-1}$ em São Luiz Gonzaga a $1.486 \mu \mathrm{g} \mathrm{C} \mathrm{g}^{-1}$ em Dourados, enquanto que, em R2, o valor máximo foi observado em São Luiz Gonzaga (Tabela 3). Contudo, considerando-se o CV máximo de $35 \%$ (Tabela 2), os valores obtidos em V4 foram adequados em todos os locais, exceto em São Luiz Gonzaga (57\%) e, em R2, aceitáveis em todas as áreas, tendo variado de 12 (Londrina) a 32\% (São Luiz Gonzaga) (Tabela 3).

Os valores de respiração basal (RB) também diferiram entre os seis locais amostrados e, tanto em V4 como em R2, o CV esteve dentro dos limites considerados aceitáveis, exceto novamente em V4, em São Luiz Gonzaga (60\%) (Tabela 3). O quociente metabólico $\left(q \mathrm{CO}_{2}\right)$ indicou que a população microbiana em Dourados apresentou alta eficiência metabólica em V4, mas não em R2, ao contrário da população em São Luiz Gonzaga, onde, mais uma vez, o CV em V4 foi elevado (Tabela 3). A biomassa microbiana varia em função do ciclo das culturas, da incorporação de resíduos vegetais, da pluviometria e do $\mathrm{pH}$ do solo, entre outros (Wardle, 1998; Franchini et al., 2007), de modo que um ou mais desses fatores podem estar associados às variações na biomassa microbiana entre duas avaliações (Tabela 3). Os CVs elevados em São Luiz Gonzaga podem estar relacionados à homogeneidade da área.

De um modo geral, os maiores valores de CBM e NBM foram constatados no PP (Tabela 4), provavelmente porque todas as áreas foram conduzidas sob o sistema convencional, e a incorporação dos restos culturais estimulou a atividade microbiana. Considerandose o limite máximo de 35\% para o CV (Tabela 2), somente dois tratamentos em Londrina apresentaram maior variabilidade no PP (transgênico + herbicida convencional e 'Conquista' + herbicida convencional). Não houve tendência de um dos dois parâmetros (CBM ou NBM) apresentar menor CV. Em geral, os maiores

Tabela 2. Classificação( ${ }^{(1)}$ dos coeficientes de variação $(C V)$, segundo as estimativas das médias aritméticas $(\overline{\mathrm{x}})$ e do desviopadrão (s) das médias dos CVs, obtidos nas avaliações realizadas nos Ensaios 1 e 2.

\begin{tabular}{|c|c|c|c|c|c|c|c|}
\hline \multirow[t]{2}{*}{ Parâmetro $^{(2)}$} & \multirow{2}{*}{$\begin{array}{c}\text { № de } \\
\text { observações }\end{array}$} & \multirow[t]{2}{*}{$\overline{\mathrm{x}}$} & \multirow[t]{2}{*}{$\mathrm{s}$} & \multicolumn{4}{|c|}{$\mathrm{CV}$} \\
\hline & & & & Baixo & Médio & Alto & Muito alto \\
\hline \multicolumn{8}{|c|}{ Parâmetros com variabilidade alta } \\
\hline CBM & 56 & 21,9 & 11,8 & $<10,1$ & 10,1 a 33,6 & 33,6 a 45,4 & $>45,4$ \\
\hline NBM & 45 & 23,9 & 11,8 & $<12,0$ & 12,0 a 35,7 & 35,7 a 47,5 & $>47,5$ \\
\hline $\mathrm{NN}$ & 25 & 24,9 & 12,8 & $<12,0$ & 12,0 a 37,7 & 37,7 a 50,6 & $>50,6$ \\
\hline MNS & 25 & 20,7 & 11,9 & $<8,8$ & 8,8 a 32,6 & 32,6 a 44,5 & $>44,5$ \\
\hline \multicolumn{8}{|c|}{ Parâmetros com variabilidade média } \\
\hline Log $n^{\circ}$ de nódulos & 25 & 4,9 & 2,5 & $<2,5$ & 2,5 a 7,4 & 7,4 a 9,9 & $>9,9$ \\
\hline MPAS & 25 & 12,0 & 6,0 & $<6,0$ & 6,0 a 17,9 & 17,9 a 23,9 & $>23,9$ \\
\hline NPA $(\%)$ & 25 & 8,6 & 3,3 & $<5,3$ & 5,3 a 11,8 & 11,8 a 15,1 & $>15,1$ \\
\hline NTPA & 25 & 13,1 & 5,1 & $<8,0$ & 8,0 a 18,2 & 18,2 a 23,3 & $>23,3$ \\
\hline N-ureídos (\%) & 25 & 3,4 & 1,8 & $<1,6$ & 1,6 a 5,2 & 5,2 a 7,0 & $>7,0$ \\
\hline NTU & 25 & 15,6 & 5,7 & $<9,9$ & 9,9 a 21,2 & 21,2 a 26,9 & $>26,9$ \\
\hline
\end{tabular}

${ }^{(1)}$ Segundo Garcia (1989). ${ }^{(2)}$ CBM: carbono da biomassa microbiana; NBM: nitrogênio da biomassa microbiana; NN: número de nódulos; MNS: massa de nódulos secos; MPAS: massa de matéria seca da parte aérea; NPA: percentagem de nitrogênio na parte aérea; NTPA: nitrogênio total na parte aérea; N-ureídos: percentagem de nitrogênio na forma de ureídos; NTU: nitrogênio total sob a forma de ureídos. 
valores de CBM e NBM foram constatados em Ponta Grossa, mas valores elevados também foram observados em Planaltina e em duas coletas em Sete Lagoas, esta última, inclusive, com os maiores valores observados em R8. Em razão do período de seca acentuado em Ponta Grossa e Londrina houve uma queda drástica na biomassa microbiana do solo em R8, e o mesmo foi constatado em Sete Lagoas em R2 (Tabela 4).

Wardle (1992) ressaltou que períodos curtos de deficiência hídrica resultam em morte de uma porção significativa da biomassa microbiana. A robustez dos dados também foi avaliada pelo índice de variabilidade temporal (Wardle, 1998), baseado no princípio de que, se os organismos são mais resistentes aos distúrbios ambientais, a variabilidade das medidas associadas a essa biota será menor.

No Ensaio 1, os CVs relativos à $\mathrm{RB}$ e ao $\mathrm{CBM}$ obtidos em V4 não diferiram daqueles obtidos em $\mathrm{R} 2(\mathrm{p}=0,252$, para a $R B$ e $p=0,393$, para o $C B M$ ), o que indica estabilidade dos parâmetros no tempo. No Ensaio 2, o CV do CBM em PP não diferiu estatisticamente daquele obtido em R2 ( $p=0,808$ ), e o de R2 não diferiu do obtido em R8 ( $\mathrm{p}=0,538)$. O mesmo ocorreu com o parâmetro de NBM entre o PP e R2 ( $p=0,221)$, e o PP e R8 $(\mathrm{p}=0,896)$. Esses resultados dão maior suporte à utilização do CBM e do NBM em estudos de análise de risco ambiental, ou como bioindicadores de qualidade do solo.

No Ensaio 2, não foi constatada diferença estatística entre os herbicidas convencional e específico, no CBM e no NBM. As exceções ocorreram em Ponta Grossa, em duas das seis avaliações, onde a biomassa foi inferior com a aplicação do herbicida convencional, mas o oposto ocorreu em R8 em Londrina, e no PP em Brasília e Sete
Lagoas (Tabela 4). Dados da literatura indicam que, quando a BMé analisada por um período maior de tempo, em geral, os efeitos dos herbicidas são de menor importância e intensidade do que os de outros agrotóxicos, por exemplo, os fungicidas (Topp et al., 1997). Também deve ser considerado o fato de as doses empregadas in vitro serem, em geral, superiores àquelas utilizadas no campo. Além disso, parte do herbicida aplicado não atinge o solo, outra parte é retida pela vegetação e o herbicida que atinge o solo é parcialmente degradado e adsorvido (Grossbard, 1985). Mesmo nos casos em que foi verificada toxidez dos herbicidas aos microrganismos, ocorreu recuperação da população microbiana com a degradação do produto químico (Topp et al., 1997). Em um estudo conduzido por 35 anos no Canadá com 2,4-D, por exemplo, não houve efeito significativo na biomassa e na respiração microbiana, nas taxas de mineralização do $\mathrm{N}$, na nitrificação e em diversas enzimas do solo, como a urease, fosfatase ou desidrogenase (Topp et al., 1997).

Em relação ao efeito das cultivares, de modo geral, não houve diferença entre a 'Conquista' e o evento transgênico, nos parâmetros de biomassa microbiana (Tabela 4) e, na análise conjunta dos dados de todos os locais, os dois materiais não diferiram estatisticamente $(\mathrm{p}=0,056)$; contudo, deve-se salientar que o valor de $\mathrm{p}$ encontrado está próximo ao da significância de 5\%. $\mathrm{O}$ tratamento com o evento transgênico que recebeu herbicida específico também não diferiu da cultivar Conquista tratada com herbicida convencional $(\mathrm{p}=0,161)$.

O uso de parâmetros microbiológicas, para avaliar a qualidade do solo ou em ensaios de monitoramento, tem

Tabela 3. Carbono da biomassa microbiana $\left(\mathrm{CBM}, \mu \mathrm{g} \mathrm{C} \mathrm{g}{ }^{-1}\right)$, respiração basal $\left(\mathrm{RB}, \mu \mathrm{g}\right.$ de $\mathrm{C}-\mathrm{CO}_{2} \mathrm{~g}^{-1}$ dia $\left.^{-1}\right)$ e quociente metabólico $\left[q \mathrm{CO}_{2},\left(\mu \mathrm{g}\right.\right.$ de $\mathrm{CO}_{2} \mu \mathrm{g}^{-1} \mathrm{C}$ microbiano $\left.{ }^{-1}\right)$ x $\left.10^{4}\right]$, em solos de seis locais do Brasil. Solos coletados nos estádios V4 e R2 da cultura da soja. Médias e coeficiente de variação $(\mathrm{CV})$ de três repetições, com duas análises por repetição. Ensaio 1, soja convencional, safra 2002/2003.

\begin{tabular}{|c|c|c|c|c|c|c|c|}
\hline \multirow[t]{2}{*}{ Local } & \multirow[t]{2}{*}{ Variável } & \multicolumn{3}{|c|}{ V4 } & \multicolumn{3}{|c|}{$\mathrm{R} 2$} \\
\hline & & CBM & $\mathrm{RB}$ & $q \mathrm{CO}_{2}$ & CBM & RB & $q \mathrm{CO}_{2}$ \\
\hline \multirow[t]{2}{*}{ São Luiz Gonzaga } & Média & 203,0 & 2,10 & 3,48 & 968,7 & 3,80 & 1,71 \\
\hline & $\mathrm{CV}$ & 56,7 & 59,8 & 49,7 & 31,5 & 7,9 & 23,1 \\
\hline \multirow[t]{2}{*}{ Passo Fundo } & Média & 398,3 & 2,57 & 2,79 & 500,7 & 2,78 & 2,31 \\
\hline & $\mathrm{CV}$ & 33,0 & 26,5 & 24,0 & 22,7 & 23,7 & 3,9 \\
\hline \multirow[t]{2}{*}{ Cascavel } & Média & 642,3 & 2,52 & 1,69 & 209,3 & 1,14 & 2,33 \\
\hline & $\mathrm{CV}$ & 31,2 & 10,3 & 18,3 & 13,7 & 15,0 & 28,0 \\
\hline \multirow[t]{2}{*}{ Ponta Grossa } & Média & 229,7 & 1,05 & 1,92 & 300,3 & 1,26 & 1,75 \\
\hline & $\mathrm{CV}$ & 14,6 & 7,2 & 11,2 & 12,8 & 11,1 & 1,7 \\
\hline \multirow[t]{2}{*}{ Londrina } & Média & 248,3 & 1,04 & 1,76 & 427,3 & 1,97 & 1,94 \\
\hline & $\mathrm{CV}$ & 16,7 & 6,4 & 13,2 & 11,7 & 2,6 & 11,2 \\
\hline \multirow[t]{2}{*}{ Dourados } & Média & $1.485,7$ & 4,48 & 1,27 & 226,0 & 1,77 & 3,38 \\
\hline & $\mathrm{CV}$ & 15,6 & 2,8 & 11,8 & 22,6 & 2,0 & 24,5 \\
\hline
\end{tabular}


sido adotado com freqüência, uma vez que os parâmetros microbiológicos apresentam maior sensibilidade às alterações ambientais do que os parâmetros químicos e físicos (Franchini et al., 2007). Os resultados obtidos no presente estudo indicam que as avaliações quantitativas da biomassa microbiana (CBM, RB e NBM), com três (Ensaio 1) ou quatro (Ensaio 2) repetições, apresentam baixa variabilidade, mesmo em solos bastante distintos,

Tabela 4. Carbono e nitrogênio da biomassa microbiana (CBM e NBM, $\mu \mathrm{g} \mathrm{C}$ ou N g ${ }^{-1}$ ), em solos de sete locais do Brasil, sob três tratamentos com soja, em amostras coletadas nos estádios de pré-plantio, R2 e R8. Ensaio 2, safra 2003/2004 ${ }^{(1)}$.

\begin{tabular}{|c|c|c|c|c|c|c|c|}
\hline \multirow[t]{2}{*}{ Tratamento } & \multirow[t]{2}{*}{ Variável } & \multicolumn{2}{|c|}{ Pré-plantio } & \multicolumn{2}{|c|}{ R2 } & \multicolumn{2}{|c|}{$\mathrm{R} 8$} \\
\hline & & CBM & NBM & CBM & NBM & CBM & NBM \\
\hline \multirow{3}{*}{ Transgênico + herbicida específico } & \multicolumn{7}{|c|}{ Ponta Grossa } \\
\hline & Média & $857,7 \mathrm{a}$ & $101,4 \mathrm{a}$ & $626,4 a$ & $70,1 \mathrm{a}$ & $395,4 a$ & $45,7 \mathrm{a}$ \\
\hline & $\mathrm{CV}$ & 14,4 & 26,4 & 5,6 & 6,8 & 18,7 & 10,6 \\
\hline \multirow[t]{2}{*}{ Transgênico + herbicida convencional } & Média & $693,7 b$ & $83,8 \mathrm{a}$ & $623,8 \mathrm{a}$ & $59,0 \mathrm{~b}$ & $410,3 a$ & $43,6 \mathrm{a}$ \\
\hline & $\mathrm{CV}$ & 10,9 & 32,4 & 13,5 & 14,8 & 34,8 & 7,8 \\
\hline \multirow[t]{2}{*}{ Conquista + herbicida convencional } & Média & $839,0 \mathrm{a}$ & $92,2 \mathrm{a}$ & $634,1 \mathrm{a}$ & $73,1 \mathrm{a}$ & $349,4 a$ & $50,8 \mathrm{a}$ \\
\hline & $\mathrm{CV}$ & 18,0 & 11,3 & 20,8 & 20,8 & 17,6 & 19,3 \\
\hline \multirow{3}{*}{ Transgênico + herbicida específico } & & & & Londrina & & & \\
\hline & Média & $543,3 a$ & $16,2 b$ & $390,2 \mathrm{ab}$ & $38,7 \mathrm{a}$ & $143,3 b$ & $14,6 \mathrm{a}$ \\
\hline & $\mathrm{CV}$ & 22,2 & 30,9 & 24,6 & 33,6 & 28,2 & 22,9 \\
\hline \multirow[t]{2}{*}{ Transgênico + herbicida convencional } & Média & $453,7 \mathrm{a}$ & $24,1 \mathrm{a}$ & $433,5 \mathrm{a}$ & $49,0 \mathrm{a}$ & $341,0 \mathrm{a}$ & $21,2 \mathrm{a}$ \\
\hline & $\mathrm{CV}$ & 37,0 & 31,2 & 21,3 & 45,3 & 46,6 & 66,2 \\
\hline \multirow[t]{2}{*}{ Conquista + herbicida convencional } & Média & $253,7 \mathrm{~b}$ & $16,1 \mathrm{~b}$ & $305,6 b$ & $38,6 \mathrm{a}$ & $407,6 \mathrm{a}$ & $17,2 \mathrm{a}$ \\
\hline & $\mathrm{CV}$ & 52,2 & 11,8 & 45,9 & 33,8 & 26,8 & 36,2 \\
\hline & \multicolumn{7}{|c|}{ Santo Antônio de Posse } \\
\hline \multirow[t]{2}{*}{ Transgênico + herbicida específico } & Média & $329,6 a$ & $17,3 \mathrm{a}$ & $305,0 \mathrm{a}$ & $35,4 \mathrm{a}$ & $374,4 \mathrm{a}$ & $26,1 \mathrm{a}$ \\
\hline & $\mathrm{CV}$ & 9,6 & 24,2 & 22,3 & 19,4 & 19,2 & 26,2 \\
\hline \multirow[t]{2}{*}{ Transgênico + herbicida convencional } & Média & $304,0 \mathrm{a}$ & $15,6 \mathrm{a}$ & $345,9 \mathrm{a}$ & $37,3 \mathrm{a}$ & $413,8 \mathrm{a}$ & $24,8 \mathrm{a}$ \\
\hline & $\mathrm{CV}$ & 10,9 & 34,8 & 10,9 & 28,3 & 17,1 & 27,5 \\
\hline \multirow[t]{2}{*}{ Conquista + herbicida convencional } & Média & $253,0 \mathrm{~b}$ & $17,6 \mathrm{a}$ & $350,3 \mathrm{a}$ & $35,6 a$ & $389,5 \mathrm{a}$ & $28,4 \mathrm{a}$ \\
\hline & $\mathrm{CV}$ & 11,0 & 31,5 & 15,0 & 14,3 & 28,3 & 21,3 \\
\hline \multirow{3}{*}{ Transgênico + herbicida específico } & \multicolumn{7}{|c|}{ Sete Lagoas } \\
\hline & Média & $578,9 \mathrm{~b}$ & $89,1 \mathrm{a}$ & $146,8 \mathrm{a}$ & $14,0 \mathrm{a}$ & $562,6 \mathrm{a}$ & $60,8 \mathrm{a}$ \\
\hline & $\mathrm{CV}$ & 16,6 & 27,2 & 4,3 & 18,1 & 7,4 & 16,8 \\
\hline \multirow[t]{2}{*}{ Transgênico + herbicida convencional } & Média & $667,0 \mathrm{a}$ & $97,2 \mathrm{a}$ & $151,7 \mathrm{a}$ & $15,1 \mathrm{a}$ & $550,5 \mathrm{a}$ & $54,8 \mathrm{a}$ \\
\hline & $\mathrm{CV}$ & 25,1 & 18,6 & 35,0 & 15,1 & 30,1 & 17,9 \\
\hline \multirow[t]{2}{*}{ Conquista + herbicida convencional } & Média & $746,2 \mathrm{a}$ & $107,6 \mathrm{a}$ & $150,0 \mathrm{a}$ & $12,3 \mathrm{a}$ & $679,6 \mathrm{a}$ & $55,5 \mathrm{a}$ \\
\hline & $\mathrm{CV}$ & 15,0 & 18,9 & 5,4 & 17,2 & 25,9 & 15,1 \\
\hline & & & & Planaltina & & & \\
\hline Transgênico + herbicida específico & Média & $590,2 \mathrm{a}$ & $65,5 \mathrm{a}$ & $459,6 \mathrm{a}$ & $43,3 \mathrm{a}$ & - & - \\
\hline & $\mathrm{CV}$ & 7,5 & 20,3 & 7,4 & 20,7 & - & - \\
\hline Transgênico + herbicida convencional & Média & $549,9 a$ & $54,5 \mathrm{a}$ & $440,3 \mathrm{a}$ & $46,3 \mathrm{a}$ & - & - \\
\hline & $\mathrm{CV}$ & 19,4 & 14,8 & 13,4 & 8,0 & - & - \\
\hline Conquista + herbicida convencional & Média & $597,4 a$ & $78,6 \mathrm{a}$ & $441,5 \mathrm{a}$ & $41,0 \mathrm{a}$ & - & - \\
\hline & $\mathrm{CV}$ & 7,2 & 21,0 & 6,9 & 4,8 & - & - \\
\hline & & & & Brasília & & & \\
\hline Transgênico + herbicida específico & Média & $449,6 \mathrm{a}$ & $34,4 b$ & $291,3 \mathrm{a}$ & $40,5 \mathrm{a}$ & $445,6 \mathrm{a}$ & $26,4 \mathrm{a}$ \\
\hline & $\mathrm{CV}$ & 21,1 & 35,0 & 15,0 & 8,3 & 12,9 & 29,6 \\
\hline Transgênico + herbicida convencional & Média & $442,2 \mathrm{a}$ & $47,8 \mathrm{a}$ & $267,4 a$ & $45,7 \mathrm{a}$ & $384,3 \mathrm{a}$ & $31,2 \mathrm{a}$ \\
\hline & $\mathrm{CV}$ & 18,6 & 10,9 & 29,8 & 12,1 & 19,0 & 34,3 \\
\hline Conquista + herbicida convencional & Média & $451,9 \mathrm{a}$ & $53,3 \mathrm{a}$ & $322,2 \mathrm{a}$ & $47,3 \mathrm{a}$ & $374,3 \mathrm{a}$ & $33,9 a$ \\
\hline & $\mathrm{CV}$ & 32,8 & 20,5 & 37,4 & 29,8 & 23,9 & 32,4 \\
\hline & & & & Antônio de & & & \\
\hline Transgênico + herbicida específico & Média & $335,4 a$ & $6,3 \mathrm{a}$ & $343,9 \mathrm{a}$ & $23,0 \mathrm{a}$ & - & - \\
\hline & $\mathrm{CV}$ & 15,9 & 10,6 & 31,4 & 24,7 & - & - \\
\hline Transgênico + herbicida convencional & Média & $317,5 \mathrm{a}$ & $9,0 \mathrm{a}$ & $340,7 \mathrm{a}$ & $25,2 \mathrm{a}$ & - & - \\
\hline & $\mathrm{CV}$ & 6,5 & 34,6 & 33,7 & 18,9 & - & - \\
\hline Conquista + herbicida convencional & Média & $377,2 \mathrm{a}$ & $7,3 \mathrm{a}$ & $347,8 \mathrm{a}$ & $19,8 \mathrm{a}$ & - & - \\
\hline & $\mathrm{CV}$ & 27,0 & 31,3 & 28,9 & 24,6 & - & - \\
\hline
\end{tabular}

${ }^{(1)}$ Médias e coeficiente de variação (CV) de quatro repetições, com duas avaliações por repetição; valores seguidos por letras iguais, na mesma coluna, para cada local, não diferem entre si (Duncan, $\mathrm{p}<0,05$ ). 
o que confirma a viabilidade de utilização dos parâmetros microbiológicos em larga escala.

A técnica de DGGE representa um grande avanço nos estudos de microbiologia do solo, por conseguir detectar microrganismos não-cultiváveis; os resultados obtidos nessa análise apresentam melhor nível de resolução e relação custo/benefício, em comparação aos outros métodos disponíveis (Hungria et al., 2003).

No Ensaio 1, as análises do DNA total do solo por DGGE, com primers para a região do DNA que codifica o gene ribossomal 16S de bactérias, indicaram que a diversidade dos gêneros e espécies de bactérias, em cada área, era distinta, embora várias bandas fossem comuns a todas as áreas. Londrina apresentou a menor diversidade, o que pode ser decorrente do uso agrícola intensivo desses solos. Os perfis obtidos em cada uma das três repetições, de cada área, foram bastante semelhantes entre si, com coeficientes de similaridade de 99,9\% em Cascavel, Ponta Grossa e Dourados, de 95\% em Londrina e de $90 \%$ em Passo Fundo; menor similaridade só foi observada em São Luiz Gonzaga, de $79 \%$. A diversidade elevada em São Luiz Gonzaga, em adição à variabilidade nas análises de biomassa microbiana (Tabela 3), é indicação de menor homogeneidade microbiológica da área.

No Ensaio 2, nas avaliações de DGGE realizadas no PP e em R2, similaridade superior a $90 \%$ entre as quatro repetições foi confirmada em todos os locais, exceto pelo tratamento 1 no PP e em R2 em Brasília e Ponta Grossa (Figura 1 e Tabela 5). A seguir, as quatro repetições de cada tratamento foram combinadas duas a duas (repetições $1+3$ e $2+4$ ); o DNA da amostra combinada foi extraído novamente e analisado, para se verificar a possibilidade de juntar amostras e diminuir os custos. Tanto os perfis, como os índices de similaridade foram semelhantes aos da primeira análise, conduzida com quatro repetições. Na Figura 1, são mostrados os perfis obtidos na análise conjunta (duas repetições) em duas situações. No caso de Santo Antônio de Posse, os perfis obtidos entre as repetições no PP foram semelhantes, e o mesmo fato aconteceu com os perfis entre os tratamentos em PP e em R2, o que indica homogeneidade da área; além disso, a maioria das bandas observadas nos perfis obtidos na amostragem do PP foi confirmada em R2 (Figura 1). Em Brasília, a homogeneidade entre as repetições no PP foi menor, particularmente no tratamento 1, e os perfis obtidos no PP foram bastante distintos daqueles obtidos em R2 (Figura 1). No caso dos perfis distintos entre as coletas, sabe-se que a microbiota do solo é fortemente estimulada pela rizosfera. Por exemplo, a população de rizóbios microssimbiontes do feijoeiro é estimulada na germinação e no florescimento (Hungria et al., 2003). No caso do presente estudo, no primeiro ano do Ensaio 2, não foram constatadas diferenças qualitativas na microbiota do solo relacionadas à transgenia ou à composição do herbicida, e foi maior a diferença, em alguns locais, verificada entre as coletas.

As seis áreas avaliadas no Ensaio 1 apresentaram

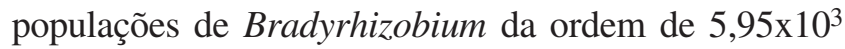
(Passo Fundo) a $37,4 \times 10^{3}$ células $\mathrm{g}^{-1}$ de solo seco (Cascavel) (Tabela 6), com CV bastante elevado, de 49 a 130\%; após a transformação logarítmica, procedimento freqüentemente utilizado para esse parâmetro (Woomer et al., 1988), houve um decréscimo do CV para 5,2\% e 15,8\%, respectivamente (Tabela 6). Também nos solos utilizados no Ensaio 2, exceto o de Brasília ( $<10$ células $\left.\mathrm{g}^{-1}\right)$, as populações de rizóbios

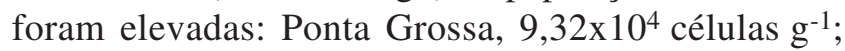
Londrina, $1,47 \times 10^{5}$ células $\mathrm{g}^{-1}$; Santo Antônio de Posse, $4,27 \times 10^{3}$ células $\mathrm{g}^{-1}$; Sete Lagoas, $1,72 \times 10^{4}$ células $\mathrm{g}^{-1}$; Planaltina, $3,98 \times 10^{3}$ células $\mathrm{g}^{-1}$; e Santo Antônio de Goiás, $1,47 \times 10^{2}$ células $\mathrm{g}^{-1}$.

Em relação ao NN, o CV no Ensaio 1 variou de 7,9\% (Ponta Grossa) ao máximo de 16,2\% (São Luiz Gonzaga) e, para a massa de nódulos secos (MNS), de 6,6\% (Londrina) a 20,4\% (Dourados), o que dispensa a necessidade de transformação dos dados (Tabela 6). No Ensaio 2, nos locais onde houve deficiência hídrica (Sete Lagoas e Santo Antônio de Goiás), ou baixa população de rizóbios (Brasília), CVs elevados (35\%) foram observados (Tabela 7). Em ambos os ensaios, o CV para a MNS foi inferior ao constatado para o NN (Tabelas 6 e 7).

$\mathrm{Na}$ análise de ocupação dos nódulos, a soma das percentagens de nódulos ocupados por cada sorogrupo foi superior a $100 \%$, pois vários nódulos apresentaram ocupação por mais de uma estirpe; além disso, de 2,6\% (Dourados) a 10,2\% (Londrina) foram ocupados por estirpes com sorogrupos desconhecidos (Tabela 6), o que também é relatado em diversos ensaios conduzidos no Brasil (Hungria et al., 2006). A maior percentagem de nódulos apresentou reação sorológica com a SEMIA 5079, o sorogrupo mais competitivo e utilizado por mais tempo em inoculantes comerciais (Mendes et al., 2004; Hungria et al., 2006). A variabilidade nos parâmetros de ocupação dos nódulos, pelos diversos sorogrupos, foi aceitável no caso das estirpes mais competitivas (SEMIAs 587, 5019 e 5079) (Tabela 6), 
Santo Antônio de Posse

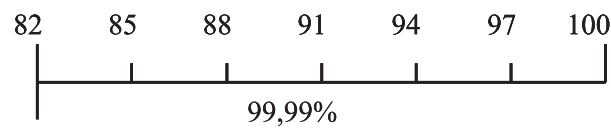

$99,99 \%$

$99,99 \%$

$99,99 \%$

$99,99 \%$
Amostragem no pré-plantio
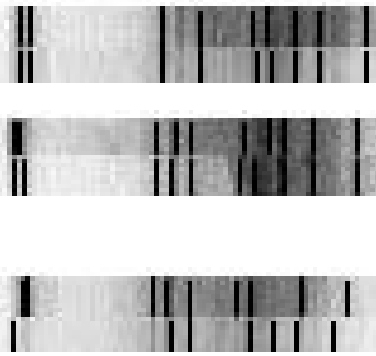

Amostragem no pré-plantio

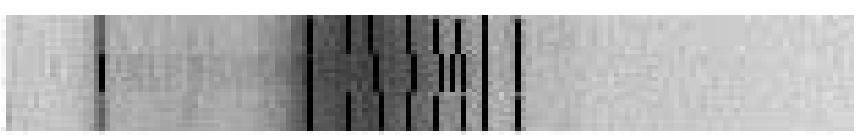

Amostragem em R2

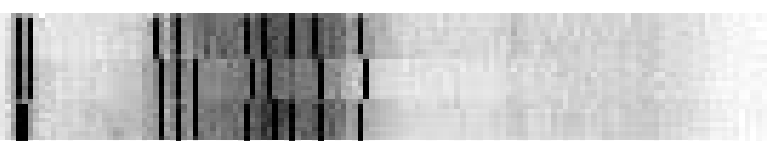

Tratamento 1

Tratamento 2

Tratamento 3

Tratamento 1

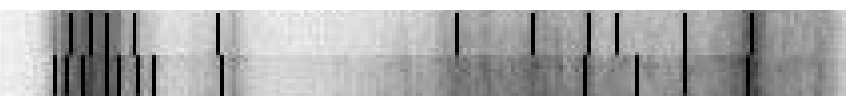

Tratamento 2
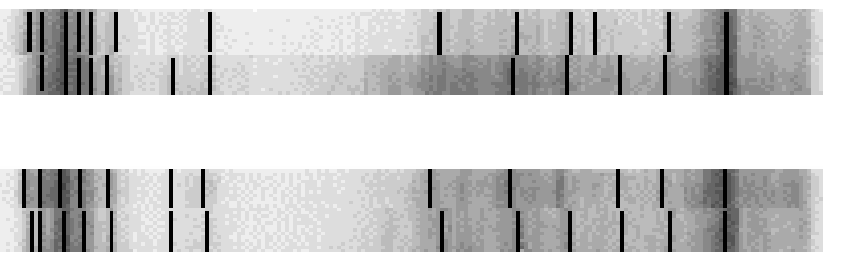

Tratamento 3

Amostragem no pré-plantio

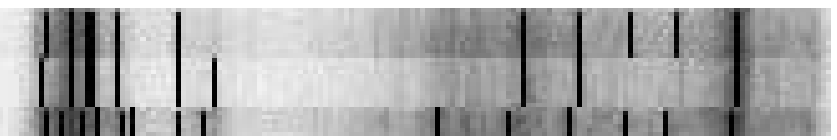

Tratamento 1

Tratamento 2

Tratamento 3

Amostragem em R2

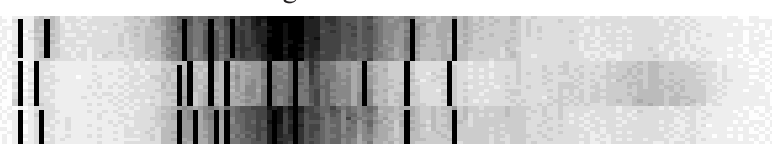

Tratamento 1

Tratamento 2

Tratamento 3

Figura 1. Similaridade genética (\%) entre os perfis de DNA total do solo, obtidos em três tratamentos no Ensaio 1 ( tratamento 1, 'Conquista' transgênica + herbicida específico; tratamento 2, 'Conquista' transgênica + herbicida convencional; tratamento 3, 'Conquista' convencional + herbicida convencional), em experimentos conduzidos em Santo Antônio da Posse e em Brasília (Ensaio 2), nas coletas do pré-plantio e R2. Os perfis foram obtidos após a amplificação com primers para a região do gene ribossomal $16 \mathrm{~S}$ e eletroforese por DGGE. Os produtos foram analisados com o programa Bionumerics, com o algoritmo UPGMA, o coeficiente de Jaccard e um índice de tolerância de 5\%. 
contudo, CVs elevados foram observados com as estirpes menos competitivas, por exemplo, em Passo
Fundo, a SEMIA 5080 ocupou, em média, 12\% dos nódulos, com CV de 44,4\%. Coeficientes de variação

Tabela 5. Percentagem de similaridade genética final obtida pela análise de agrupamento dos produtos obtidos por DGGE do DNA total do solo amplificado com primers para a região que codifica para o gene ribossomal 16S de bactérias. Foram realizadas análises de agrupamento entre as repetições de cada tratamento e entre tratamentos em cada coleta. Os produtos de PCR foram analisados usando o programa Bionumerics com o algoritmo UPGMA e o coeficiente de Jaccard, com um nível de tolerância de 5\%. Ensaio 2, safra 2003/2004.

\begin{tabular}{|c|c|c|c|c|}
\hline \multirow[t]{3}{*}{ Tratamento } & \multicolumn{4}{|c|}{ Similaridade genética $(\%)$} \\
\hline & \multicolumn{2}{|c|}{ Entre repetições } & \multicolumn{2}{|c|}{ Entre tratamentos (final) } \\
\hline & Pré-plantio & $\mathrm{R} 2$ & Pré-plantio & $\mathrm{R} 2$ \\
\hline $\begin{array}{l}\text { Transgênico + herbicida específico } \\
\text { Transgênico }+ \text { herbicida convencional } \\
\text { Conquista + herbicida convencional }\end{array}$ & $\begin{array}{l}99,99 \\
99,99 \\
99,99\end{array}$ & $\begin{array}{l}\text { Ponta } \\
61,54^{(1)} \\
83,33 \\
81,82\end{array}$ & 93,33 & $73,34^{(2)}$ \\
\hline $\begin{array}{l}\text { Transgênico + herbicida específico } \\
\text { Transgênico + herbicida convencional } \\
\text { Conquista + herbicida convencional }\end{array}$ & $\begin{array}{l}99,99 \\
99,99 \\
99,99\end{array}$ & $\begin{array}{l}\text { Lon } \\
99,99 \\
99,99 \\
99,99 \\
\end{array}$ & 99,99 & 99,99 \\
\hline $\begin{array}{l}\text { Transgênico + herbicida específico } \\
\text { Transgênico }+ \text { herbicida convencional } \\
\text { Conquista + herbicida convencional }\end{array}$ & $\begin{array}{l}99,99 \\
99,99 \\
99,99\end{array}$ & $\begin{array}{l}\text { to Antô1 } \\
99,99 \\
99,99 \\
99,99\end{array}$ & 99,99 & 99,99 \\
\hline $\begin{array}{l}\text { Transgênico + herbicida específico } \\
\text { Transgênico }+ \text { herbicida convencional } \\
\text { Conquista + herbicida convencional }\end{array}$ & $\begin{array}{l}90,91 \\
99,99 \\
99,99\end{array}$ & $\begin{array}{l}\text { Sete I } \\
90,91 \\
99,99 \\
99,99 \\
\end{array}$ & 90,91 & 90,91 \\
\hline $\begin{array}{l}\text { Transgênico + herbicida específico } \\
\text { Transgênico }+ \text { herbicida convencional } \\
\text { Conquista + herbicida convencional }\end{array}$ & $\begin{array}{l}90,01 \\
99,99 \\
99,99\end{array}$ & $\begin{array}{l}\text { Plan } \\
89,89^{(1} \\
90,01 \\
89,89^{(3}\end{array}$ & 90,91 & 90,01 \\
\hline $\begin{array}{l}\text { Transgênico + herbicida específico } \\
\text { Transgênico + herbicida convencional } \\
\text { Conquista + herbicida convencional }\end{array}$ & $\begin{array}{l}87,51 \\
92,86 \\
99,99\end{array}$ & $\begin{array}{r}\text { Bra } \\
99,99 \\
99,99 \\
99,99\end{array}$ & $84,38^{(3)}$ & 99,99 \\
\hline $\begin{array}{l}\text { Transgênico + herbicida específico } \\
\text { Transgênico }+ \text { herbicida convencional } \\
\text { Conquista + herbicida convencional }\end{array}$ & $\begin{array}{l}99,99 \\
99,99 \\
99,99\end{array}$ & $\begin{array}{c}\text { to Antô1 } \\
99,99 \\
99,99 \\
99,99 \\
\end{array}$ & 99,99 & 99,99 \\
\hline
\end{tabular}

${ }^{(1)}$ Considerado como $90 \%$. (2) Similaridade entre os tratamentos 2 e 3, 83,33\% e, deste agrupamento em relação ao tratamento 1 , 73,34\%.

${ }^{(3)}$ Similaridade entre os tratamentos 2 e 3,92,86\% e, deste agrupamento em relação ao tratamento $1,84,38 \%$.

Tabela 6. Número de células de Bradyrhizobium por grama de solo; número de nódulos por planta (NN); massa de nódulos secos por planta (MNS, mg); ocupação dos nódulos pelas estirpes (\%); massa de matéria seca da parte aérea (MPAS, gramas por planta); $\mathrm{N}$ total acumulado na parte aérea (NTPA, miligramas por planta); percentual do N total na forma de ureídos (NU); $\mathrm{N}$ total na forma de ureídos (NTU, miligramas por planta); eficiência dos nódulos considerando-se o N total (ENNT, mg N g-1 de nódulo) e o N na forma de ureídos (ENNU, mg N ureído $\mathrm{g}^{-1}$ de nódulo), em soja no estádio R2, coletada em seis áreas produtoras. Médias e coeficientes de variação (CV, \%) de três repetições. Ensaio 1, soja convencional, safra 2002/2003.

\begin{tabular}{|c|c|c|c|c|c|c|c|c|c|c|c|c|c|c|c|c|}
\hline \multirow[t]{2}{*}{ Local } & \multirow[t]{2}{*}{ Variável } & \multicolumn{2}{|c|}{ Células de rizóbios } & \multicolumn{2}{|c|}{ Nodulação $^{(1)}$} & \multicolumn{5}{|c|}{ Ocupação dos nódulos ${ }^{(2)}$} & \multicolumn{4}{|c|}{ Parte aérea $^{(1)}$} & \multicolumn{2}{|c|}{ Efic. nódulos ${ }^{(1)}$} \\
\hline & & $\mathrm{n}^{\mathrm{o}}\left(\mathrm{x} 10^{3}\right)$ & $(\log )$ & $\mathrm{NN}$ & $\overline{\mathrm{MNS}}$ & 587 & 5019 & 5079 & 5080 & S/reação & MPAS & NTPA & NU\% & NTU & ENNT & ENNU \\
\hline \multirow{2}{*}{ São Luiz Gonzaga } & Média & 7,74 & 3,81 & 114 & 241 & 43,1 & 36,3 & 55,1 & 6,7 & 6,6 & 2,44 & 95,4 & 77,8 & 74,3 & 0,40 & 0,31 \\
\hline & $\mathrm{CV}$ & 77,7 & 8,1 & 16,2 & 14,8 & 11,0 & 7,3 & 8,9 & 17,7 & 20,8 & 6,8 & 11,1 & 1,9 & 12,8 & 4,2 & 2,4 \\
\hline \multirow[t]{2}{*}{ Passo Fundo } & Média & 5,95 & 3,74 & 125 & 258 & 43,0 & 42,5 & 44,9 & 12,1 & 4,6 & 2,42 & 97,1 & 77,2 & 75,3 & 0,38 & 0,29 \\
\hline & $\mathrm{CV}$ & 49,0 & 5,2 & 15,4 & 14,6 & 8,3 & 5,0 & 10,4 & 44,4 & 46,5 & 9,5 & 12,4 & 4,5 & 16,6 & 4,1 & 2,6 \\
\hline \multirow[t]{2}{*}{ Cascavel } & Média & 37,40 & 4,26 & 126 & 251 & 36,1 & 29,6 & 49,5 & 19,7 & 7,4 & 3,03 & 124,3 & 75,0 & 93,4 & 0,50 & 0,37 \\
\hline & $\mathrm{CV}$ & 130,0 & 15,8 & 10,8 & 12,1 & 18,6 & 15,5 & 1,5 & 15,6 & 54,0 & 2,3 & 4,2 & 5,5 & 9,6 & 9,2 & 4,8 \\
\hline \multirow[t]{2}{*}{ Ponta Grossa } & Média & 22,24 & 4,26 & 103 & 209 & 39,3 & 26,9 & 39,9 & 12,0 & 6,4 & 2,57 & 98,6 & 72,1 & 71,1 & 0,47 & 0,34 \\
\hline & $\mathrm{CV}$ & 80,6 & 8,0 & 7,9 & 9,6 & 5,7 & 15,4 & 7,4 & 29,1 & 33,3 & 11,8 & 13,2 & 2,6 & 14,3 & 6,5 & 9,0 \\
\hline \multirow[t]{2}{*}{ Londrina } & Média & 17,09 & 3,96 & 106 & 192 & 34,8 & 23,1 & 40,6 & 12,9 & 10,2 & 2,56 & 105,3 & 80,3 & 84,6 & 0,44 & 0,55 \\
\hline & $\mathrm{CV}$ & 129,9 & 14,6 & 9,4 & 6,6 & 11,0 & 9,7 & 9,4 & 10,9 & 25,5 & 4,4 & 4,9 & 2,4 & 7,2 & 3,4 & 4,2 \\
\hline \multirow[t]{2}{*}{ Dourados } & Média & 20,56 & 4,14 & 91 & 133 & 30,9 & 23,1 & 48,4 & 25,4 & 2,6 & 2,85 & 106,6 & 80,9 & 86,3 & 0,82 & 0,66 \\
\hline & $\mathrm{CV}$ & 96,7 & 12,1 & 14,4 & 4,0 & 15,8 & 14,3 & 18,6 & 8,9 & 15,4 & 4,2 & 6,5 & 1,7 & 8,9 & 15,1 & 13,5 \\
\hline
\end{tabular}

(1)Médias de dez plantas por repetição. (2)Médias de 40 nódulos retirados de dez plantas por repetição. 
elevados para a ocupação dos nódulos também foram verificados em outros ensaios, conduzidos a campo no Brasil, por exemplo, de $38 \%$ em Londrina, PR (Hungria et al., 1998) a 61\% em Planaltina, DF (Mendes et al., 2004).
Nas avaliações de massa e $\mathrm{N}$ total na parte aérea, os CVs foram baixos em todos os locais, com valor máximo de 13,2\% no Ensaio 1 (Tabela 6) e de 24,6\% no Ensaio 2 (Tabela 7), ambos para o NTPA em Ponta Grossa.

Tabela 7. Número de nódulos por planta (NN), massa de nódulos secos por planta (MNS, mg), massa de matéria seca da parte aérea (MPAS, gramas por planta), teor de N (\%NPA), N total (NTPA, mg de N por planta), teor de N-ureídos (NU) e N total na forma de ureídos (NTU, mg de N-ureído por planta) na parte aérea da soja. Eficiência dos nódulos considerando-se o N total (ENNT, mg N g-1 de nódulo) e o $\mathrm{N}$ na forma de ureídos (ENNU, mg N-ureído g-1 de nódulo), em soja no estádio R2, coletada em sete áreas produtoras. Ensaio 2, safra 2004/2005(1).

\begin{tabular}{|c|c|c|c|c|c|c|c|c|c|c|}
\hline \multirow[t]{2}{*}{ Tratamento } & \multirow[t]{2}{*}{ Variável } & \multicolumn{2}{|c|}{ Nodulação } & \multicolumn{5}{|c|}{ Parte aérea } & \multicolumn{2}{|c|}{ Eficiência dos nódulos } \\
\hline & & $\mathrm{NN}$ & MNS & MPAS & $\% \mathrm{NPA}$ & NTPA & NU & NTU & ENNT & ENNU \\
\hline \multirow{3}{*}{ Transgênico + herbicida específico } & \multicolumn{10}{|c|}{ Ponta Grossa } \\
\hline & Média & $136 \mathrm{a}$ & $484 a$ & $37,8 \mathrm{a}$ & $40,3 a$ & $1522 \mathrm{a}$ & $86,8 \mathrm{a}$ & $1327 \mathrm{a}$ & $3,1 \mathrm{a}$ & $2,7 \mathrm{a}$ \\
\hline & $\mathrm{CV}$ & 10,8 & 11,8 & 20,8 & 12,4 & 24,6 & 2,7 & 27,6 & 14,4 & 16,9 \\
\hline \multirow[t]{2}{*}{ Transgênico + herbicida convencional } & Média & $114 \mathrm{a}$ & $383 a$ & $36,6 \mathrm{a}$ & $41,4 \mathrm{a}$ & $1514 \mathrm{a}$ & $85,8 \mathrm{a}$ & $1302 \mathrm{a}$ & $4,0 \mathrm{a}$ & $3,4 \mathrm{a}$ \\
\hline & $\mathrm{CV}$ & 23,8 & 17,5 & 10,4 & 8,3 & 11,2 & 2,6 & 13,7 & 23,3 & 25,2 \\
\hline \multirow[t]{2}{*}{ Conquista + herbicida convencional } & Média & $97 \mathrm{a}$ & $358 \mathrm{a}$ & $37,2 \mathrm{a}$ & $39,7 \mathrm{a}$ & $1473 \mathrm{a}$ & $85,2 \mathrm{a}$ & $1255 \mathrm{a}$ & $4,1 \mathrm{a}$ & $3,5 \mathrm{a}$ \\
\hline & $\mathrm{CV}$ & 44,8 & 34,4 & 8,2 & 11,5 & 11,3 & 0,6 & 11,7 & 27,8 & 27,4 \\
\hline \multirow{3}{*}{ Transgênico + herbicida específico } & \multicolumn{10}{|c|}{ Londrina } \\
\hline & Média & $87 \mathrm{ab}$ & $184 b$ & $11,7 \mathrm{a}$ & $41,0 \mathrm{a}$ & $475 b$ & $73,5 \mathrm{a}$ & $350 \mathrm{a}$ & $2,6 \mathrm{a}$ & $1,9 \mathrm{a}$ \\
\hline & $\mathrm{CV}$ & 42,6 & 27,9 & 13,8 & 13,2 & 6,8 & 3,9 & 10,2 & 41,6 & 45,7 \\
\hline \multirow[t]{2}{*}{ Transgênico + herbicida convencional } & Média & $109 a$ & $232 a$ & $14,4 a$ & $41,2 \mathrm{a}$ & $586 \mathrm{ab}$ & $74,0 \mathrm{a}$ & $437 a$ & $2,5 \mathrm{a}$ & $1,9 \mathrm{a}$ \\
\hline & $\mathrm{CV}$ & 5,8 & 8,7 & 26,9 & 9,4 & 20,4 & 5,8 & 25,7 & 29,0 & 35,1 \\
\hline \multirow[t]{2}{*}{ Conquista + herbicida convencional } & Média & $63 b$ & $166 \mathrm{~b}$ & $14,6 \mathrm{a}$ & $42,8 \mathrm{a}$ & $624 a$ & $72,8 \mathrm{a}$ & $456 \mathrm{a}$ & $3,8 \mathrm{a}$ & $2,7 \mathrm{a}$ \\
\hline & $\mathrm{CV}$ & 10,9 & 18,6 & 19,0 & 5,3 & 19,1 & 3,9 & 22,4 & 42,1 & 45,0 \\
\hline \multirow{3}{*}{ Transgênico + herbicida específico } & \multicolumn{10}{|c|}{ Santo Antônio de Posse } \\
\hline & Média & $72 \mathrm{a}$ & $234 \mathrm{a}$ & $28,2 \mathrm{a}$ & $36,1 \mathrm{a}$ & $1.007 \mathrm{~b}$ & $83,0 \mathrm{a}$ & $838 b$ & $4,3 b$ & $3,6 b$ \\
\hline & $\mathrm{CV}$ & 38,5 & 5,6 & 13,0 & 11,5 & 7,5 & 4,2 & 11,6 & 4,2 & 7,8 \\
\hline \multirow[t]{2}{*}{ Transgênico + herbicida convencional } & Média & $80 \mathrm{a}$ & $200 \mathrm{a}$ & $33,7 \mathrm{a}$ & $36,2 \mathrm{a}$ & $1.221 \mathrm{a}$ & $86,0 \mathrm{a}$ & $1.050 \mathrm{a}$ & $6,1 \mathrm{a}$ & $5,2 \mathrm{a}$ \\
\hline & $\mathrm{CV}$ & 24,7 & 25,6 & 8,4 & 8,8 & 12,7 & 0,9 & 13,1 & 42,8 & 42,8 \\
\hline \multirow[t]{2}{*}{ Conquista + herbicida convencional } & Média & $69 \mathrm{a}$ & $230 \mathrm{a}$ & $29,9 \mathrm{a}$ & $36,6 \mathrm{a}$ & $1.090 \mathrm{~b}$ & $85,5 \mathrm{a}$ & $933 b$ & $4,7 \mathrm{~b}$ & $4,0 \mathrm{~b}$ \\
\hline & $\mathrm{CV}$ & 40,1 & 10,4 & 15,7 & 12,3 & 16,6 & 0,7 & 17,1 & 9,4 & 9,4 \\
\hline & \multicolumn{10}{|c|}{ Sete Lagoas } \\
\hline Transgênico + herbicida específico & Média & $107 \mathrm{a}$ & $223 b$ & $11,1 \mathrm{~b}$ & $36,4 \mathrm{a}$ & $406 \mathrm{a}$ & $73,8 \mathrm{a}$ & $301 \mathrm{a}$ & $1,8 \mathrm{a}$ & $1,3 \mathrm{a}$ \\
\hline & $\mathrm{CV}$ & 42,3 & 31,8 & 7,7 & 12,9 & 20,1 & 4,0 & 23,8 & 38,4 & 41,1 \\
\hline Transgênico + herbicida convencional & Média & $126 \mathrm{a}$ & $244 \mathrm{a}$ & $11,9 \mathrm{~b}$ & $35,2 \mathrm{a}$ & $420 \mathrm{a}$ & $77,2 \mathrm{a}$ & $323 a$ & $1,7 \mathrm{a}$ & $1,3 a$ \\
\hline & $\mathrm{CV}$ & 30,2 & 46,1 & 9,7 & 5,5 & 13,2 & 8,1 & 9,3 & 55,2 & 61,1 \\
\hline Conquista + herbicida convencional & Média & $141 \mathrm{a}$ & $322 \mathrm{a}$ & $13,2 \mathrm{a}$ & $35,6 a$ & $472 \mathrm{a}$ & $72,8 \mathrm{a}$ & $343 a$ & $1,5 \mathrm{a}$ & $1,1 \mathrm{a}$ \\
\hline & $\mathrm{CV}$ & 23,5 & 13,5 & 7,2 & 8,8 & 14,9 & 3,9 & 15,2 & 6,6 & 4,7 \\
\hline & & & & & Plar & tina & & & & \\
\hline Transgênico + herbicida específico & Média & $87 \mathrm{a}$ & $324 a$ & $18,0 \mathrm{~b}$ & $37,9 a$ & $682 b$ & $86,0 \mathrm{a}$ & $590 \mathrm{~b}$ & $2,1 \mathrm{a}$ & $1,8 \mathrm{a}$ \\
\hline & $\mathrm{CV}$ & 21,1 & 22,5 & 16,1 & 8,1 & 15,8 & 5,8 & 21,4 & 17,3 & 19,8 \\
\hline Transgênico + herbicida convencional & Média & $99 \mathrm{a}$ & $352 \mathrm{a}$ & $22,3 a$ & $37,9 a$ & $846 a$ & $88,2 \mathrm{a}$ & $749 a$ & $2,4 \mathrm{a}$ & $2,1 \mathrm{a}$ \\
\hline & $\mathrm{CV}$ & 25,8 & 28,2 & 12,6 & 2,6 & 14,0 & 3,7 & 17,7 & 42,3 & 45,9 \\
\hline Conquista + herbicida convencional & Média & $90 \mathrm{a}$ & $379 a$ & $19,3 b$ & $35,0 \mathrm{a}$ & $672 b$ & $84,8 \mathrm{a}$ & $572 b$ & $0,18 \mathrm{a}$ & $1,5 \mathrm{a}$ \\
\hline & $\mathrm{CV}$ & 28,4 & 25,2 & 15,1 & 3,8 & 15,8 & 2,9 & 18,4 & 30,1 & 31,1 \\
\hline & & & & & & & & & & \\
\hline Transgênico + herbicida específico & Média & $0,4 \mathrm{a}$ & $5 \mathrm{a}$ & $17,7 \mathrm{a}$ & $37,8 \mathrm{a}$ & $671 \mathrm{a}$ & & & & \\
\hline & $\mathrm{CV}$ & 126,7 & 129,2 & 12,1 & 12,9 & 20,0 & & & & \\
\hline Transgênico + herbicida convencional & Média & $0,3 \mathrm{a}$ & $3 a$ & $20,9 \mathrm{a}$ & $37,0 \mathrm{a}$ & $773 a$ & & & & \\
\hline & $\mathrm{CV}$ & 75,0 & 87,1 & 20,6 & 7,9 & 21,2 & & & & \\
\hline Conquista + herbicida convencional & Média & $1,0 \mathrm{a}$ & $6 a$ & $14,7 \mathrm{a}$ & $36,2 \mathrm{a}$ & $535 \mathrm{a}$ & & & & \\
\hline & $\mathrm{CV}$ & 128,2 & 109,1 & 12,4 & 7,8 & 16,9 & & & & \\
\hline & & & & & anto Anto & o de Goiá & & & & \\
\hline Transgênico + herbicida específico & Média & $26 a$ & $108 \mathrm{~b}$ & $17,6 \mathrm{ab}$ & $37,6 \mathrm{a}$ & $661 \mathrm{ab}$ & $81,8 \mathrm{a}$ & $541 \mathrm{ab}$ & $6,1 \mathrm{ab}$ & $5,0 \mathrm{ab}$ \\
\hline & $\mathrm{CV}$ & 42,7 & 41,0 & 7,2 & 6,1 & 9,6 & 1,5 & 10,9 & 46,4 & 44,9 \\
\hline Transgênico + herbicida convencional & Média & $20 \mathrm{a}$ & $94 \mathrm{~b}$ & $19,5 \mathrm{a}$ & $39,2 \mathrm{a}$ & $761 \mathrm{a}$ & $84,2 \mathrm{a}$ & $644 a$ & $8,1 \mathrm{a}$ & $6,8 \mathrm{a}$ \\
\hline & $\mathrm{CV}$ & 39,8 & 42,2 & 18,2 & 7,0 & 16,7 & 3,9 & 20,5 & 38,6 & 37,7 \\
\hline Conquista + herbicida convencional & Média & $22 a$ & $132 \mathrm{a}$ & $15,1 b$ & $39,7 \mathrm{a}$ & $596 \mathrm{~b}$ & $82,0 \mathrm{a}$ & $490 b$ & $4,5 b$ & $3,7 b$ \\
\hline & $\mathrm{CV}$ & 26,9 & 7,7 & 18,3 & 6,2 & 11,9 & 2,8 & 14,6 & 9,7 & 11,6 \\
\hline
\end{tabular}

${ }^{(1)}$ Médias e coeficiente de variação $(\mathrm{CV}, \%)$ considerando-se quatro repetições, com a avaliação de dez plantas por repetição; valores seguidos por letras iguais, na mesma coluna, para cada local, não diferem entre si (Duncan, $\mathrm{p}<0,05$ ). 
Na quantificação do processo de FBN, foi utilizado o método da abundância relativa de $\mathrm{N}$ dos ureídos, pelo baixo custo e por não necessitar de controles sem FBN. No Ensaio 1, a contribuição da FBN variou de 72 a $81 \%$ (Tabela 6) e, no Ensaio 2, de 73 a 88\% (Tabela 7) do $\mathrm{N}$ total das plantas. Esses valores estão de acordo com um levantamento de ensaios de quantificação conduzidos no Brasil, que indicou contribuições de 69 a $94 \%$ (Hungria et al., 2006).

A variabilidade nas avaliações de $\mathrm{N}$ dos ureídos também foi baixa, com máximo de $27,6 \%$, em Ponta Grossa (Ensaio 2) (Tabela 7). No Ensaio 2, em geral, não foram constatadas diferenças entre os herbicidas nos parâmetros de FBN (Tabela 7). Além disso, na análise geral dos dados obtidos nos sete locais, não foram constatadas diferenças entre os dois herbicidas nos seguintes parâmetros: $\mathrm{NN}(\mathrm{p}=0,458), \operatorname{MNS}(\mathrm{p}=0,300)$, MPAS $(\mathrm{p}=0,419), \%$ NPA $(\mathrm{p}=0,135)$, NTPA $(\mathrm{p}=0,425), \% \mathrm{~N}$ de ureído $(\mathrm{p}=0,476)$ e NTU $(\mathrm{p}=0,488)$. Deve-se salientar, porém, que os dados se referem apenas ao primeiro ano do ensaio.

Em estudo conduzido sobre a FBN, foi constatado que em geral os herbicidas são menos tóxicos que os fungicidas (De-Polli et al., 1986). Contudo, existe grande variação entre os princípios ativos dos herbicidas e, portanto, também são encontradas variações na toxidez à simbiose. Como exemplo, $42 \%$ dos estudos compilados por De-Polli et al. (1986) mostraram efeitos prejudiciais dos herbicidas à FBN. Em alguns casos, os herbicidas, inclusive o glifosato, reduziram drasticamente a sobrevivência do Bradyrhizobium e a nodulação da soja (Marenco et al., 1993; Zawoznik et al., 1995). Santos et al. (2004), ao analisar o crescimento in vitro das estirpes comerciais de Bradyrhizobium SEMIA 587, SEMIA 5019 e SEMIA 5079 com sete formulações comerciais de glifosato, verificaram que a magnitude do efeito variou com a estirpe e com a formulação do herbicida. De modo semelhante, Zablotowicz \& Reddy (2004) constataram diferenças entre estirpes de Bradyhrizobium, quanto à tolerância ao glifosato, o que afeta a taxa de crescimento das bactérias, a nodulação e o teor de leghemoglobina nos nódulos. É importante salientar que o Bradyrhizobium possui a enzima de sensibilidade ao glifosato, e o herbicida pode acumular-se nos nódulos, embora não tenha sido demonstrado efeito tóxico em campo (Zablotowicz \& Reddy, 2004). Finalmente, há relatos de ausência de efeito tóxico de alguns herbicidas, como foi o caso da trifluralina na nodulação e na ocupação de nódulos, em um ensaio com soja nos Cerrados (Mendes et al., 1994).
A análise conjunta dos dados, obtidos nos sete locais também indicou que não houve diferença estatística entre a cultivar Conquista convencional e o evento transgênico, nos parâmetros: $\mathrm{NN}(\mathrm{p}=0,396)$, MNS $(\mathrm{p}=0,395)$, MPAS $(\mathrm{p}=0,484)$, \% NPA $(\mathrm{p}=0,244)$, NTPA $(\mathrm{p}=0,443), \% \mathrm{~N}$-ureído $(\mathrm{p}=0,443)$ e NTU $(\mathrm{p}=0,486)$. Efeitos da transgenia, em campo, na microbiota do solo, ainda não foram demonstrados, ou ocorreram de modo variável e transiente (Dunfield \& Germida, 2004; Motavalli et al., 2004).

Neste trabalho, foram sugeridos limites aceitáveis para a variabilidade temporal e espacial, em ensaios conduzidos em campo, para os parâmetros utilizados em avaliações quantitativas e qualitativas da microbiota do solo e da FBN. Foi demonstrada a viabilidade de utilizar esses parâmetros, em larga escala e em campo, em ensaios de monitoramento, ou de análise de risco ambiental. No caso do Ensaio 2, os parâmetros foram validados em um monitoramento sobre a avaliação do efeito da transgenia e dos herbicidas, e não foram constatadas, no primeiro ano do ensaio, diferenças significativas entre os tratamentos.

\section{Conclusões}

1. O coeficiente de variação máximo aceitável é de $35 \%$, para o uso dos parâmetros de carbono e nitrogênio da biomassa microbiana como indicadores quantitativos da microbiota do solo.

2. Em relação à análise de DNA total do solo, o nível de dissimilaridade máximo aceitável entre repetições é de $10 \%$, para que as amostras sejam consideradas homogêneas.

3. Em solos pobres em nitrogênio, as massas de nódulos e da parte aérea são adequadas para avaliar o crescimento e o desempenho simbiótico da soja, desde que o coeficiente de variação não ultrapasse 33 e 18\%, respectivamente.

4. Em áreas com teores elevados ou desconhecidos de nitrogênio no solo, ou que receberam fertilizantes nitrogenados, o nitrogênio total ou o nitrogênio de ureído precisa ser analisado, e o coeficiente de variação não deve ultrapassar 18 ou $21 \%$, respectivamente.

\section{Referências}

AMARAL, A.R.; MUNIZ, J.A.; SOUZA, M.A. Avaliação do coeficiente de variação como medida da precisão na experimentação com citros. Pesquisa Agropecuária Brasileira, v.32, p.1221-1225, 1997. 
BROOKES, P.C.; LANDMAN, A.; PRUDEN, G.; JENKINSON, D.S. Chloroform fumigation and the release of soil nitrogen: a rapid direct extraction method to measure microbial biomass nitrogen in soil. Soil Biology and Biochemistry, v.17, p.837-842, 1985.

DE-POLLI, H.; SOUTO, S.M.; FRANCO, A.A. Compatibilidade de agrotóxicos com Rhizobium spp. e a simbiose das leguminosas. Seropédica: Embrapa-UAPNPBS, 1986. 71p. (Embrapa-UAPNPBS. Documentos, 3).

DUNFIELD, K.E.; GERMIDA, J.J. Impact of genetically modified crops on soil- and plant-associated microbial communities. Journal of Environmental Quality, v.33, p.806-815, 2004

FRANCHINI, J.C.; CRISPINO, C.C.; SOUZA, R.A.; TORRES, E.; HUNGRIA, M. Microbiological parameters as indicators of soil quality under various soil management and crop rotation systems in Southern Brazil. Soil and Tillage Research, v.92, p.18-29, 2007.

GARCIA, C.H. Tabelas para classificação do coeficiente de variação. Piracicaba: IPEF, 1989. 10p. (IPEF. Circular Técnica, 171).

GROSSBARD, E. Effects of glyphosate on the microflora: with reference to the decomposition of treated vegetation and interaction with some plant pathogens. In: GROSSBARD, E.; ATKINSON, D. (Ed.). The herbicide glyphosate. London: Butterworths, 1985. p.159-185.

HERRIDGE, D.F.; PEOPLES, M.B. Ureide assay for measuring nitrogen fixation by nodulated soybean calibrated by ${ }^{15} \mathrm{~N}$ methods. Plant Physiology, v.93, p.495-503, 1990.

HUNGRIA, M.; BODDEY, L.H.; SANTOS, M.A.; VARGAS, M.A.T. Nitrogen fixation capacity and nodule occupancy by Bradyrhizobium japonicum and B. elkanii strains. Biology and Fertility of Soils, v.27, p.393-399, 1998.

HUNGRIA, M.; CAMPO, R.J.; MENDES, I.C. Benefits of inoculation of common bean (Phaseolus vulgaris) crop with efficient and competitive Rhizobium tropici strains. Biology and Fertility of Soils, v.39, p.88-93, 2003.

HUNGRIA, M.; CAMPO, R.J.; MENDES, I.C.; GRAHAM, P.H. Contribution of biological nitrogen fixation to the $\mathrm{N}$ nutrition of grain crops in the tropics: the success of soybean (Glycine $\max (\mathrm{L}$.$) Merr.) in$ South America. In: SINGH, R.P.; SHANKAR, N.; JAIWAL, P.K. (Ed.). Nitrogen nutrition and sustainable plant productivity. Houston: Studium Press, LLC, 2006. p.43-93.

MARENCO, R.; LOPES, N.F.; MOSQUIM, P.R. Nodulation and nitrogen fixation in soybeans treated with herbicides. Revista Brasileira de Fisiologia Vegetal, v.5, p.121-126, 1993.

MENDES, I.C.; HUNGRIA, M.; VARGAS, M.A.T. Establishment of Bradyrhizobium japonicum and B. elkanii strains in a Brazilian Cerrado oxisol. Biology and Fertility of Soils, v.40, p.28-35, 2004.

MENDES, I.C.; SUHET, A.R.; VARGAS, M.A.T.; PERES, J.R.R.; VIVALDI, L.J. Efeitos do trifluralin e da inoculação com rizóbio na soja cultivada em solos de Cerrado. Revista Brasileira de Ciência do Solo, v.18, p.433-439, 1994.
MOTAVALLI, P.P.; KREMER, R.J.; FANG, M.; MEANS, N.E. Impact of genetically modified crops and their management on soil microbially mediated plant nutrient transformations. Journal of Environmental Quality, v.33, p.816-824, 2004.

O'DONNELL, A.G.; GORRES, H. 16S rDNA methods in soil microbiology. Current Opinion in Biotechnology, v.10, p.225229, 1999.

PIMENTEL-GOMES, F. A estatística moderna na pesquisa agropecuária. Piracicaba: Potafos, 1984. 160p.

RAMALHO, M.A.P.; FERREIRA, D.F.; OLIVEIRA, A.C. Experimentação em genética e melhoramento de plantas. 2.ed. Lavras: Ufla, 2005. 322p.

SANTOS, J.B.; JACQUES, R.J.S.; PROCÓPIO, S.O.; KASUYA, M.C.B.; SILVA, A.A.; SANTOS, E.A. Efeitos de diferentes formulações comerciais de glyphosate sobre estirpes de Bradyrhizobium. Planta Daninha, v.22, p.293-299, 2004.

SAS INSTITUTE. Proprietary of software: version $6.4^{\text {th }}$ ed. Cary: SAS Institute, 1999.

SCAPIM, C.A.; CARVALHO, C.G.P.; CRUZ, C.D. Uma proposta de classificação dos coeficientes de variação para a cultura do milho. Pesquisa Agropecuária Brasileira, v.30, p.683-686, 1995.

TOPP, E.; VALLAEYS, T.; SOULAS, G. Pesticides: microbial degradation and effects on microorganisms. In: VAN ELSAS, J.D.; TREVORS, J.T.; WELLINGTON, E.M.H. (Ed.). Modern soil microbiology. New York: Marcel Dekker, 1997. p.547-575.

VANCE, E.D.; BROOKES, P.C.; JENKINSON, D.S. An extraction method for measuring soil microbial biomass C. Soil Biology and Biochemistry, v.19, p.703-707, 1987.

WARDLE, D.A. A comparative assessment of factors which influence microbial biomass carbon and nitrogen levels in soil. Biological Reviews, v.67, p.321-358, 1992.

WARDLE, D.A. Controls of temporal variability of the soil microbial biomass: a global scale synthesis. Soil Biology and Biochemistry, v.30, p.1627-1637, 1998.

WOOMER, P.; SINGLETON, P.W.; BOHLOOL, B.B. Ecological indicators of native rhizobia in tropical soils. Applied and Environmental Microbiology, v.54, p.1112-1116, 1988.

ZABLOTOWICZ, R.M.; REDDY, K.N. Impact of glyphosate on the Bradyrhizobium japonicum symbiosis with glyphosate-resistant transgenic soybean: a minireview. Journal of Environmental Quality, v.33, p.825-831, 2004.

ZAWOZNIK, M.S.; BENAVIDES, M.P.; TOMARO, M.L. Effect of herbicide diuron on growth and symbiotic behaviour of Rhizobium and Bradyrhizobium species. European Journal of Soil Biology, v.31, p.183-188, 1995.

Recebido em 26 de abril de 2007 e aprovado em 17 de dezembro de 2007 